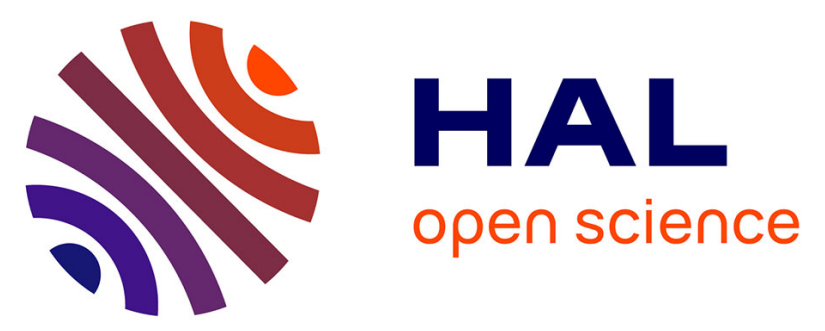

\title{
Fecal biomarker imprints as indicators of past human land uses: Source distinction and preservation potential in archaeological and natural archives
}

Renata Zocatelli, Marlène Lavrieux, Typhaine Guillemot, Léo Chassiot, Claude Le Milbeau, Jérémy Jacob

\section{To cite this version:}

Renata Zocatelli, Marlène Lavrieux, Typhaine Guillemot, Léo Chassiot, Claude Le Milbeau, et al.. Fecal biomarker imprints as indicators of past human land uses: Source distinction and preservation potential in archaeological and natural archives. Journal of Archaeological Science, 2017, 81, pp.79 89. 10.1016/j.jas.2017.03.010 . insu-01503523

\section{HAL Id: insu-01503523 \\ https://hal-insu.archives-ouvertes.fr/insu-01503523}

Submitted on 7 Apr 2017

HAL is a multi-disciplinary open access archive for the deposit and dissemination of scientific research documents, whether they are published or not. The documents may come from teaching and research institutions in France or abroad, or from public or private research centers.
L'archive ouverte pluridisciplinaire HAL, est destinée au dépôt et à la diffusion de documents scientifiques de niveau recherche, publiés ou non, émanant des établissements d'enseignement et de recherche français ou étrangers, des laboratoires publics ou privés.

\section{(1) (1) $\$$}

Distributed under a Creative Commons Attribution - NonCommercial - NoDerivatives 44.0 


\title{
Fecal biomarker imprints as indicators of past human land uses: source distinction and preservation potential in archaeological and natural archives.
}

${ }^{1}$ Université d'Orléans, Institut des Sciences de la Terre d'Orléans (ISTO), UMR 7327, 45071 Orléans, France

${ }^{2}$ CNRS/INSU, ISTO, UMR 7327, 45071 Orléans, France

${ }^{3}$ BRGM, ISTO, UMR 7327, BP 36009, 45060 Orléans, France

${ }^{4}$ Environmental Geosciences, University of Basel, Bernoullistrasse 30, 4056 Basel, Switzerland

${ }^{5}$ Eawag - Swiss Federal Institute of Aquatic Science and Technology, Seestrasse 79, 6047

Kastanienbaum, Switzerland

\begin{abstract}
This paper presents the potential of $5 \beta$-stanols and bile acids to act as fecal source biomarkers in order to identify and characterize past agropastoral activities in archaeological and natural archives. First of all, a molecular inventory of $5 \beta$-stanols and bile acids was made on fresh fecal human and domestic animal samples, using the same methodology to define the specificity of these molecular biomarkers. The selected species were cow, horse, pig and sheep as they are the major domestic species present in European archaeological sites. To our knowledge, our work constitutes the first report on fecal biomarkers in sheep feces. Bile acids can distinguish diet regime and species having the same diet with greater specificity than $5 \beta$-stanols. Fresh human fecal material and historical / archaeological fecal material were analyzed to assess their stability through time by calculating the coprostanol/epi-coprostanol (Cp/epi-Cp) and deoxycholic acid/cholic acid (DOC/C) ratios. Results show that bile acids are more resistant to diagenesis than $5 \beta$-stanols, at least on a 700-year time scale. Human and domestic animal fecal molecular imprints were then compared to the molecular content of 65 samples retrieved from archaeological sites, soils and lacustrine sediments to test their ability to trace past land-use dynamics. This study is the first to combine bile acids and $5 \beta$-stanols to identify a source of fecal material indifferent types of location (archaeological site, catchments and lacustrine sediments) and on different time scales. The combination of sterols and bile acids can be used in a variety of natural archives and archaeological contexts to define the origin of fecal material, to specify land-use, and to reconstruct past pastoral practices at various spatio-temporal scales.
\end{abstract}

Keywords: past agropastoral dynamics, fecal sterols, bile acids, archaeological and natural archives.

Corresponding author e-mail address: renata.zoccatelli1@univ-orleans.fr (R. Zocatelli). 


\section{Introduction}

Land use change is known to be one of the main factors in global change, as it affects, inter alia, biodiversity (Smith and Zeder, 2013; Braje and Erlandson, 2013), biogeochemical cycles (Foley et al., 2005), geomorphological processes (Syvitski et al., 2005; Syvitski and Kettner, 2011) and climate (IPCC, 2013; Ruddiman, 2013; Ellis et al., 2013). The development of agricultural practices, especially through animal domestication and land clearing, induced a fundamental shift in the interactions between humans and environments (Redman, 1999; Zeder et al., 2006), from local to regional and continental scales (Braje and Erlandson, 2013). To predict ecosystem responses to global changes, the characterization of past land-uses and their impacts on environment/climate systems are relevant (Ruddiman, 2003; Dearing, 2006; Hurtt et al., 2006; Jacob et al., 2009).

Fossil organic molecules or molecular biomarkers are compounds preserved in archaeological and natural (soil, sediment) archives, having an unequivocal biological source (e.g. van Bergen et al., 1997; Simoneit, 2002, Killops and Killops, 2005). Biomarker analysis can provide information on environmental conditions either in predominantly natural or in more anthropized contexts such as archaeological sites and urban areas, at local or catchment scale (e.g. Bull et al., 1998; Oldfield et al., 2003; Zolitschka and Ariztegui, 2007; Jacob et al., 2008; Battarbee and Bennion, 2011; Lavrieux et al., 2012, 2013a; Zocatelli et al., 2010, 2012, 2013).

Fecal biomarkers ( $\mathrm{C}_{27}, \mathrm{C}_{28}$ and $\mathrm{C}_{29} 5 \beta$-stanols and bile acids), produced in the digestive tracts of certain large mammals (Elhmmali et al., 2000; Bull et al., 2002; Tyagi et al., 2008) are commonly used to trace human or animal fecal inputs in current environments (Nes and Nes, 1980; Elhmmali et al., 1997; Evershed et al., 1997; Bull et al., 1998, 1999b, 2001, 2002; Jardé et al., 2007a; Lavrieux et al., 2012; D'Anjouet al., 2012; Guillemot et al., 2015, 2016). However, to date, only a few studies have precisely distinguished human and animal sources in archaeological settlements (Bull et al., 2003) or in the surrounding area (Shillito et al., 2011a). 
contexts, such as sheep, has never been investigated. Moreover, the published data were acquired using different protocols, which makes the comparison between the fecal imprints difficult.

To fill these gaps, this study proposes an integrated ("source to sink") approach to fecal biomarkers ( $5 \beta$-stanols and bile acids), from the source organisms to the archives, at different spatial and temporal scales, based on a large set of new data. First, a complete inventory of fecal biomarkers was made in current human and domestic animal feces. Cow, horse, pig and, for the first time, sheep, were selected because they represent the most abundant animals described in European archaeological sites. To identify their fecal molecular distribution, the same protocol was used, allowing a comparison between them and a characterization of the potential specificity of these biomarkers. The early and selective degradation of fecal biomarkers was then studied in order to ascertain the stability of established relationships through time. This was achieved by analyzing the molecular content of fresh human feces, recent sediments in septic tanks and archaeological middens. Finally, the fecal molecular imprints previously proposed were tested in different archives. This includes septic tanks and soils in archaeological settlements (Orléans, France), soils (Lake Aydat catchment, Massif Central, France) and lake sediments (retrieved from Lake Montcineyre, Massif Central, France and Lake Igaliku, South Greenland). These archives enable past agropastoral dynamics to be assessed at different spatio-temporal scales.

\section{Materials and methods}

\subsection{Sampling}

\subsubsection{Reference samples}

Fresh feces of humans, cows, horses, pigs and sheep constituted the reference samples. Fresh animal feces were collected at the Institut National de la Recherche Agronomique (INRA, 
98 Tours, France), whereas the human fecal material was obtained from an anonymous donor.

99 Samples were placed in thermo coolers immediately after collection $\left(-20^{\circ} \mathrm{C}\right)$.

100

101

\subsubsection{Collection samples}

102

An ancient septic tank, archaeological middens, soils and lacustrine sediments were

sampled. First, they were used to assess the early diagenesis and preservation of the fecal biomarkers' distribution through time and then for the reconstruction of past agropastoral dynamics on various space and time scales.

A total of 60 samples were selected (Appendix 1):

- Four samples were taken to assess the possible early and preferential degradation of fecal biomarkers over the first centuries after deposition: a19thcentury septic tank (St19) and three archaeological middens dated from the 14th, 15th and 16th centuries (St14, St15, St16, respectively; Joyeux, 2013) collected from undisturbed settlement layers in an excavated

111 housing located in the medieval city of Orléans (Loire Valley, France). - 10 soils (PS1-PS10), from fields pastured by bovines for at least 60 years, were sampled

113 in the Lake Aydat catchment (Massif Central, France) in order to describe the fecal molecular

114 distribution in grazing areas and their transfer to soils.

- A total of 46 samples were retrieved from two lacustrine sediment cores to reconstruct past and recent land uses at a catchment scale. Two catchments with distinct anthropogenic contexts were selected:

118 (i) Lake Montcineyre catchment (Massif Central, France) located twenty kilometers away

119 from Aydat (Fig. 1). Archaeological and historical data attest toagropastoral activities 120 since the Middle Ages (Charbonnier, 1999; Bayard, 2010 and references therein). 121 However, despite the presence of archaeological settlements in the catchment since the 122 Neolithic, agropastoral activities and their impact on the local ecosystems remain poorly understood at catchment scale (Chassiot, 2015; Chassiot et al., 2016). 13 samples were 
retrieved from a sedimentary core from Lake Montcineyre (MO1-MO13), spanning the last 800 years (Chassiot et al., 2016).

(ii) Lake Igaliku catchment, located in South Greenland. Two distinct agropastoral periods are attested regionally: the Norse settlement, between AD 986 and ca. AD 1450 and the modern period, since the 1920s (Gauthier et al., 2010; Massa et al., 2012). Located one and a half kilometers away from the lake, the village of Igaliku was the Norse episcopal capital of Greenland and one of the most important agropastoral centers, judging from archaeological structures (Arnebord et al., 2007). Nowadays, agropastoral

\subsection{Fecalbiomarkeranalyses}

138 Samples were dried at $30{ }^{\circ} \mathrm{C}$ during $48 \mathrm{~h}$ and then crushed. Ca. two grams of dried samples were extracted using an accelerated solvent extractor (Dionex ${ }^{\circledR} \mathrm{ASE} 200,100{ }^{\circ} \mathrm{C}$ and $1000 \mathrm{psi}$ ) with a mixture of $\mathrm{CH}_{2} \mathrm{Cl}_{2}: \mathrm{MeOH}(9: 1 \mathrm{v} / \mathrm{v})$. Total lipid extract was fractionated into neutral and

141 acidic compounds using solid phase extraction on Supelclean $\mathrm{LC}^{-\mathrm{NH}_{2}}$ SPE bulk packing

142 (Zocatelli et al., 2012). Neutral compounds were eluted with $\mathrm{CH}_{2} \mathrm{Cl}_{2}$ :isopropanol (2:1) and 143 acidic compounds with ether:formic acid (9:1) after acidification. Total neutral and acid 144 fractions were then dried under $\mathrm{N}_{2}$. As described in Lavrieux et al. (2011), the sterols were 145 isolated from the total neutral fraction by flash chromatography on a Pasteur pipette filled with 146 silica (activated $24 \mathrm{~h}$ at $120^{\circ} \mathrm{C}$, then deactivated with $\mathrm{H}_{2} \mathrm{O}, 5 \%$ ), using a sequence of solvents of 147 increasing polarity (heptane, heptane:toluene and heptane:ethyl acetate). The acidic fraction was methylated by adding a mixture of anhydrous $\mathrm{MeOH}$ and acetyl chloride $\left(55^{\circ} \mathrm{C}\right.$ for one hour). It was then separated into fatty acid methyl esters (FAMEs) and hydroxy acid methyl 
150 esters by flash chromatography with a Pasteur pipette filled with silica, using $\mathrm{CH}_{2} \mathrm{Cl}_{2}$,

$151 \mathrm{CH}_{2} \mathrm{Cl}_{2}$ :isopropanol and $\mathrm{MeOH}$ (Guillemot et al., 2015).Finally, sterol and bile acid fractions were silylated using BSTFA and pyridine $\left(60^{\circ} \mathrm{C}\right.$ for one hour). Prior to gas-chromatography and mass-spectrometry (GC-MS) analyses, $5 \alpha$-cholestaneand nor-deoxycholic acid standards

154 were added to all fractions for quantitation purposes.

155 Fractions were analyzed by gas chromatography-mass spectrometry (GC-MS) with a 156 Polaris TRACE-GCQ. The chromatograph was fitted with an Rtx-5MS column (30 m, $0.25 \mathrm{~mm}$ 157 i.d., $0.25 \mu \mathrm{m}$ film thickness). The GC operating conditions were: $40^{\circ} \mathrm{C}$ (hold $1 \mathrm{~min}$ ) ramping 158 from $40^{\circ} \mathrm{C}$ to $120^{\circ} \mathrm{C}$ at $30^{\circ} \mathrm{C} \cdot \mathrm{min}^{-1}$, then from $120^{\circ} \mathrm{C}$ to $300^{\circ} \mathrm{C}$ at $5^{\circ} \mathrm{C} \cdot \mathrm{min}^{-1}$, hold $30 \mathrm{~min}$. The 159 samples were injected automatically in splitless mode, with the injector temperature set at $160280^{\circ} \mathrm{C}$. Helium was the carrier gas $\left(1 \mathrm{ml} \cdot \mathrm{min}^{-1}\right)$. The MS was operated in the electron ionization

161 (EI) mode at $70 \mathrm{eV}$ and scanned from $\mathrm{m} / \mathrm{z} 50-650$. Identification of fecal biomarkers was based on published retention times and mass spectra (Elhmmali et al., 1997; Bull et al., 2001) and also on authentic standards of sterols and bile acids, obtained from Sigma Aldrich Chemical

164 Co. and Alfa Aesar. Because of possible coelution with other components, compound 165 concentrations were estimated by measuring peak areas on ion specific chromatograms. Fecal 166 biomarker concentrations were estimated after calculation of a correction factor between the 167 peak area on the ion specific chromatogram and the peak area on the total ion current (TIC) chromatogram for authentic standards. The minimum level of detection using GC-MS was about $10 \mathrm{ng}$.

\section{Results and Discussion}

\subsection{Fecal biomarker inventory}

Nine sterols (sensulato): five fecal stanols [coprostanols or $5 \alpha$-stanols, coprostanol (Cp),

174 epi-coprostanol (epi-Cp), methylcoprostanol (mCp), epi-ethylcoprostanol (epi-ethCp) and 175 ethylcoprostanol (ethCp)]; two 5 $\alpha$-stanols [(cholestanol (Chln) and ethylcholestanol (ethChln)] 
and two sterols [sensustricto; cholesterol (Chl) and sitosterol (Sit)] were detected in

177 thereference samples and alsoin the samples. In addition, six bile acidswere identified:

178 lithocholic acid (LC), deoxycholic acid (DOC), chenodeoxycholic acid (CDOC), cholic acid

179 (C), hyodeoxycholic acid (HDOC) and ursodeoxycholic acid (UDOC; Table 1 and 2).

\subsection{Biomarker distribution in fresh fecal material}

\subsubsection{Sterols}

The distribution of sterols varied widely among the considered species (Table 1; Fig. 2a and e). In the herbivorous group, cow feces showed the highest values of total coprostanols (TC, $1817 \mu \mathrm{g} / \mathrm{g}$ of dried fecal material; Table 1), followed by sheep (1302 $\mu \mathrm{g} / \mathrm{g})$ and horse $(336 \mu / g)$. In herbivorous fecal samples ethCp was the main compound followed by mCp (Table

187 1). In the omnivorous group, TC concentrations were one order of magnitude greater than in the herbivorous group, with a predominance of Cp. Human and pig feces had rather similar fecal sterol profiles. Indeed, $\mathrm{Cp}$ and ethCp were the major compounds in pig $(\mathrm{Cp}=3522 \mu \mathrm{g} / \mathrm{g}$, $48 \%$ of $\mathrm{TC}$; ethCp $=3093 \mu \mathrm{g} / \mathrm{g} ; 41 \%$ of $\mathrm{TC})$ and human feces $(\mathrm{Cp}=12251 \mu \mathrm{g} / \mathrm{g}, 71 \%$ of $\mathrm{TC}$; ethCp $=3929 \mu \mathrm{g} / \mathrm{g}, 23 \%$ of TC). However, the proportion of TC was more than twice as high

192 in human asin pig feces (Table 1). More especially, Cp contents in human feces were 3.5 times higher than in pig feces, which is consistent with previously published data (Leeming et al., 1996).

In the light of these results, the differences in fecal sterol distributions cannot distinguish

196 between mammals having the same diet. Previous studies using ratios of fecal and non-fecal

197 sterols barely succeeded in discriminating between mammals (e.g. Grimalt et al., 1990; Bull et al., 1999a, 2002, 2003; Jardé et al., 2007a,b; Shillito et al., 2011a; Baeten et al., 2012), assuming that the variations in coprostanol concentrations are not controlled by selective degradation.

200 These ratios were either developed to attest to pollution (Sr1>0.7; Grimalt et al., 1990) or to 201 identifyanimal sources (Sr2; Bull et al., 1999a): 
203 (ethCp +epi-ethCp)/(Cp +epi-Cp)

204 We tested these two ratios in the reference samples. For all of them, Sr1 values were greater 205 than 0.7 with $\operatorname{Sr} 1_{\text {human }}>\mathrm{Sr} 1_{\text {pig }}>\operatorname{Sr} 1_{\text {cow }}>\operatorname{Sr} 1_{\text {horseand }} \operatorname{Sr} 1_{\text {sheep }}$ (Table 1) indicating that omnivorous 206 animals produce more $\mathrm{Cp}$ than herbivorous animals. The $\mathrm{Sr} 2$ ratio, used to distinguish ruminant 207 from pig/human material sources, was below 1.0 for human and pig feces $(0.32$ and 0.76 , 208 respectively), and above 1.0 for herbivorous feces (horse $=2.29$, sheep $=2.67$ and cow $=3.05$ ). 209 As expected, $\mathrm{Sr} 1$ and $\mathrm{Sr} 2$ ratios measured in the reference samples corroborated previous 210 studies conducted by Grimalt et al. (1990) and Bull et al. (1999a,b,c, 2002) and can be 211 considered reliable as long as there is no selective degradation and/or mixing of different animal 212 imprints.

\subsubsection{Bile acids}

The distribution of bile acids also varied widely among the different animal species (Table

216 1; Figure $2 \mathrm{~b}$ and $\mathrm{f}$ ). In the herbivorous group, all species produced DOC, whereas LC was only 217 produced by cows and horses (Fig. 2b). It is therefore possible to distinguish them from sheep, 218 whose feces only contained DOC $(3.21 \mu \mathrm{g} / \mathrm{g}$ of dried fecal material). Cows and horses can be 219 distinguished by the total bile acid content, which was twice as high in cow $(0.56 \mu \mathrm{g} / \mathrm{g})$ as in 220 horse feces $(1.17 \mu \mathrm{g} / \mathrm{g})$.

221 In the omnivorous group, human and pig fecal material can be discriminated by the bile 222 acid composition. In human fecal samples, DOC was the major bile acid detected, followed by

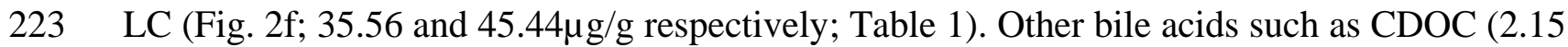
$\mu \mathrm{g} / \mathrm{g}), \mathrm{C}(1.79 \mu \mathrm{g} / \mathrm{g})$ and UDOC $(1.24 \mu \mathrm{g} / \mathrm{g})$ were detected in lower contents. While DOC was the most abundant bile acid in human fecal material, it was not detected in pig fecal samples.

226 In the latter, the major bile acids found were HDOC $(32.01 \mu \mathrm{g} / \mathrm{g})$ followed by LC $(21.07 \mu \mathrm{g} / \mathrm{g})$ 227 and UDOC in lower contents $(2.31 \mu \mathrm{g} / \mathrm{g})$. Thus, bile acid distributions allow a clear distinction 
not only between herbivorous and omnivorous mammals, but also between animals having the same diet.The fecal molecular inventory of a large range of animal feces presented in this study not only confirms, but also completes previous studies (Bethell et al., 1994; Elhmmali et al. 1997; Bull et al. 2002, 2003; Tyagi et al., 2008). Indeed, to our knowledge, our work constitutes the first report onfecal biomarkers in sheep feces.

\subsection{Fecal signal preservation}

Some studies attest to a rapid degradation of coprostanols by anaerobic bacteria present in sewage and natural waters (Gaskell and Eglinton, 1974; Grimalt et al., 1990), potentially masking their original sources (Mermoud et al., 1984; Rushdi et al., 2006). Nevertheless,in soils, other studies showed that these biomarkers are able to survive and highlight human activities during several millennia (Pepe and Dizabo, 1990; Bethell et al., 1994; Shillito et al., 2011a, b), assuming good preservation of these biomarkers. Few studies have attempted to assess such discrepancies. Elhmmali et al. (1997) showed that DOC was better preserved than

Cp in sewage particulate organic matter before and after microbiological treatments, suggesting that bile acids are probably better preserved than sterols.

To better assess the respective preservation of fecal biomarkers, we compared the fecal imprint of the human reference sample to samples from the septic tank and from archaeological middens, covering the 19th to the 14th centuries (St19, St16, St15 and St14). All these samples were characterized by a major/exclusive human fecal input. InSt19, St16, St15 and St14 samples, Sr1 values ranged between 0.87 and 0.92 (Table 2) and Sr2 exhibited low values (0.330.84), all attesting toan omnivorous fecal imprint. In addition, $\mathrm{Cp}$ was the major sterol observed (between 0.58 and $10.54 \mathrm{mg} / \mathrm{g}$ ), followed by ethCp (Fig. 2; Table 1). These indices,associated to the presence of CDOC and $\mathrm{C}$, and the absence of HDOC, attest to a human fecal input. 
254 decreasing occupation of the site. Preservation of fecal biomarkers in human feces over time

255 was assessed through the calculation of theCp/epi-Cpand DOC/C ratios.The $\mathrm{Cp} / \mathrm{epi}-\mathrm{Cp}$ ratio is

256 already used to overcome possible diagenetic biases related to the degradation of $\mathrm{Cp}$ into epi-

257 Cp (Simpson et al., 1998; Bull et al., 1999a).In addition to this ratio, we used the DOC/C ratio

258 because DOC is a secondary by-product of $\mathrm{C}$ formed in anaerobic environments via enzymatic

259 reactions (Bull et al., 2003). A relatively low DOC/C ratio variability over time indicates good

260 preservation. The DOC/C ratio can be used if it is assumed that the chemical difference between

261 DOC and $\mathrm{C}$ is minor, implying that the polarity difference between the two compounds is

262 negligible and thus would not affect the solubility and adsorption to soil/sediment particulates.

263 From today to the 14th century, the DOC/C ratio remainedconstant in our samples (DOC/C

$264 \sim 20$, Fig. 3e), whereas the Cp/epi-Cp ratiodecreasedduring the first century (from $\sim 70$ to

$265 \sim 10$ ).Assuming that this decrease in the Cp/epi-Cp ratio is not related to diet changes over

266 centuries, it would suggest a greater degradation of fecal sterols than of bile acids. This better

267 preservation of bile acids compared to $5 \beta$-stanols supports previous observations made by

268 Elhmmali et al. (1997). Regarding these results, it appears that bile acids are better preserved,

269 at least at the multi-centennial scale.

270

271

\subsection{Applications of fecal biomarkers to reconstruct agropastoral activities}

To trace and characterize past agropastoral activities in and outside archaeological sites, we applied the fecal biomarker distribution defined from our reference samples to several natural archives over various temporal scales. 


\subsubsection{Aydat catchment soils}

281 In soil samples retrieved from lake Aydat catchment (Massif Central, France), previous studies based on fecal biomarkers evidenced recent husbandry practices (Lavrieux et al., 2012; Zocatelli et al., 2012). Here, this was achieved by re-exploiting the dataset of fecal biomarker distribution and comparing it to the reference samples. The distribution of sterols and bile acids was quite similar over soil samples (Table 2, Fig. 4), with TC varying between 0.56 and $26.9 \mathrm{mg} / \mathrm{g}$ soil, and with 8-37\% of coprostanols (ethCp and Cp; Table 2). Samples also contained significant amounts of LC and DOC (0.08-0.36 and 0.84-4.25 $\mu \mathrm{g} / \mathrm{g})$. No HDOC, which is specific of pig feces, was detected. Associated to the distribution of sterols, the identification of DOC and the absence of $\mathrm{C}$ and CDOC argue for a fecal input from cows to the soil, consistent with current husbandry in the catchment. In any case, this study shows that the recent fecalcompoundsdistribution istransferred to soils andconsistent with current agropastoral practices. For paleosoils located in archaeological sites fecal biomarkers are a promising tool inarchaeological research regarding the use of space and human activities.

\subsubsection{Lake Montcineyre sediments}

A high diversity of fecal biomarkers was inventoried in the 800-yr-long lacustrine core retrieved from Lake Montcineyre. Fecal biomarkers such as Cp, epi-Cp, mCp, ethCp, epiethCp, LC and DOC were detected all along the core. Fig.5b shows the evolution of total coprostanols, $\mathrm{Sr} 2$ ratio, LC and DOC. Although a small amount of Cp was detected, the absence of CDOC, $\mathrm{C}$ and UDOC indicates that there was no significant fecal human input (Table 2, Fig. 5). Sr2 values above 1 together with DOC concentrations seven times higher than LC concentration over the whole archive are indicative of the presence of livestock composed mainly of cows over the last 800 years (Fig. 5b). Intervals with higher DOC and LC concentrations could indicate periods of increased agro-pastoral activities. Conversely, because 
acidsand fecal sterols. In view ofthe better preservation of bile acids compared to that of $5 \beta$ -

307 stanols confirmed and described in section 3.3., it isthe evolution of LC and DOC 308 biomarkersthat describes agropastoral activities during the last 800 years in the Montcineyre 309 catchment.

\subsubsection{Lake Igaliku sediments}

The regional historical context of SouthGreenland is very different from that of the

313 Massif Central. In the lake Aydat and Montcineyre catchments, agropastoral activities occurred

314 without interruption since the Neolithic. In South Greenland only two agropastoral periods (the

315 Norse settlement between AD 986 to AD 1450 and the last century) are attested. Figure 6

316 shows the evolution of TC, Sr2 ratio and DOC contents during the last two millennia. The $\mathrm{Sr} 2$

317 ratio and DOC contents evidence the two phases synchronous with these two periods of 318 agropastoralism. As here, Guillemot et al. (2015) identified two main peaks of DOC Igaliku

319 lacustrine sediments. During the last century, $\mathrm{Sr} 2$ values above 10 attest to the presence of 320 herbivorous livestock grazing in the catchment. High contents of ethCp associated to the 321 presence of DOC as the only bile acid suggest a predominant sheep fecal input. This is 322 confirmed by current agropastoral activities which are mainly characterized by sheep breeding 323 (Austrheim et al., 2008). In the Norse period, less information concerning agropastoral activities are available. In south Greenland, three archeological studies showed a predominance of ovine bones with, among others, cow and pig bones (McGovern, 1983; Edvardsson et al., 2007; Madsen, 2014). In the sediments of Lake Igaliku, a maximum of Sr2 at 26 is recorded and evidences herbivorous livestock grazing around Lake Igaliku; low $\mathrm{Cp}$ contents and the absence of CDOC, $\mathrm{C}$ and UDOC indicate no significant human fecal contribution while a similar fecal biomarker imprint was identified during the last century. High contents of ethCp and the presence of DOC alone suggest that Norse livestock was mainly composed of sheep, as

331 confirmed by archaeozoological data (McGovern, 1983; Edvardsson et al., 2007; Madsen, 
332 2014). Considering the climatic and environmental conditions of south Greenland (positive

333 temperatures only seven months a year and difficulties to cultivate fodders; Austrheim et al.,

334 2008; Cappelen, 2014), as sheep are more resistant to cold conditions and needed less fodder

335 than cows, it would be logical that the Norse Greenlandic livestocks were mainly constituted

336 of sheep, as nowadays. Between the two agropastoral phases of sheep breeding, TC and DOC

337 contents drop, attesting to a decrease of pastoral activities around Igaliku.

338 This study has provided new insight in to the determination of fecal material sources from

339 biomarkers in natural archives. A further step will be to interpret the varying concentrations of

340 biomarkers in terms of livestock population changes. This should be achieved through a

341 calibration aiming at establishing quantitative relationships and taking into account production,

342 transport and sedimentationprocesses (Eglinton and Eglinton, 2008).

\section{Conclusions}

Fecal molecular imprints of the most abundant big mammals encountered in archaeological sites in Europe were defined, using a unique extraction protocol on fresh cow, horse, sheep, pig and human feces. This study determined the fecal molecular distribution of sheep faeces. The sterol distribution in mammal feces clearly discriminates omnivorous (human and pig) from herbivorous (cow, horse and sheep) animals, but does not allow any differentiation at the species level. However, the bile acid patterns offer an unequivocal imprint for most of the species considered. Comparing fecal biomarkers in fresh human feces with an ancient septic tank and archaeological middens with known human fecal pollution showed that bile acids are better preserved over time than sterols, as suggested by previous studies. In the light of all these results, it is now possible to discriminate human and domestic animal species, using fecal molecular biomarkers and especially bile acids, showing a better specificity and preservation. 
and lacustrine sediments, aged from the last decennia to millennia. A complete fecal molecular

359 inventory in the Lake Aydat catchment soils, Lake Montcineyre and Lake Igaliku sediments is

made and brings information about past land uses, allowing a reconstruction of local past

pastoral practices and enlightening us on past interactions between human and environments.

\section{Acknowledgments}

The work received financial support from the OTARIE Project (Région Centre, European Council) and the ERODE Project (EC2CO, CNRS/INSU).We thank theInstitut National de la Recherche Agronomique (INRA) for the reference samples, Pascal Joyeux (INRAP), and Emmanuel Chapron (GEODE UMR 5602 CNRS,University of Toulouse). We also thank the French Polar Institute (IPEV) and the ANR CEP\&S "Green Greenland" project (ANR-10CELP-0008) and particularly Vincent Bichet, Emilie Gauthier, Hervé Richard (Chronoenvironnement UMR 6249,University Franche-Comté)and anonymous donors for sampling authorizations and/or providing some of the collection and reference samples. We would also like to thank the two anonymous reviewers for suggestions and comments which have helped to improve the quality of this manuscript.

\section{References}

Arneborg, J., 2007. Saga trails. In: Brattahlid G (ed.) HvalseyFjord's Church and Heljolfnesnes: Four Chieftain's Framsteads in the North Settlements of Greenland. A Visitor's Guidebook. Copenhagen: The National Museum of Denmark,94 pp.

Austrheim, G., Asheim, L.-J., Bjarnason, G., Feilberg, J., Fosaa, A. M., Holand, Ø., Jónsdóttir, I. S., Magnússon, B., Mortensen, L. E., Mysterud, A., Olsen, E., Skonhoft, A., Steinheim,G., Thórhallsdóttir, A. G. 2008: Sheep grazing in the North-Atlantic region - a longterm perspectiveon management, resource economy and ecology. Norges TekniskNaturvitenskapelige Universitet, Vitenskapsmuseet, Trondheim, Rapport Zoologisk Serie 2008-3, 1-86.

Baeten, J., Marinova, E., De Laet, V., Degryse, P., De Vos, D., Waelkens, M., 2012. Fecal biomarker and archaeobotanical analyses of sediments from a public latrine shed new light on ruralisation in Sagalassos, Turkey. Journal of Archaeological Science 39, 1143-1159.

Battarbee, R.W., Bennion, H., 2011. Palaeolimnology and its developing role in assessing the history and extent of human impact on lake ecosystems. Journal of Paleolimnology 45, 399-404.

Bayard, A., 2010. Les lieux élitaires du premier Moyen-âge en Auvergne: vecteurs de création de réseaux et de production de territoires? Apports croisés des données textuelles et matérielles. PhD Thesis. Université Paris I-Panthéon-Sorbonne, 81-104.

Bethell, P.H., Goad, L.J., Evershed, R.P., Ottaway, J., 1994. The study of molecular markers of human activity: the use of coprostanol in the soil as an indicator of human fecal material.Journal of Archaeological Science 21, 619-632.

Braje, T.J., Erlandson, J.M., 2013. Human acceleration of animal and plant extinctions: A Late Pleistocene, Holocene and Anthropocene continuum. Anthropocene 4, 14-23.

Bull, I.D., Elhmmali, M.M., Roberts, D.J., Evershed, R.P., 2003. The application of steroidal biomarkers to track the abandonment of a Roman waste water course at the agora (Athens, Greece). Archaeometry 45, 149-161.

Bull, I.D., Lockheart, M.J., Elhmmali, M.M., Roberts, D.J., Evershed, R.P., 2002. The origin of faeces by means of biomarker detection. Environment International 27, 647-654. 
Bull, I.D., Betancourt, P.P., Evershed, R.P., 2001. An organic geochemical investigation of the practice of manuring ata Minoan site on Pseira Island, Crete. Geoarchaeology 16, 223-242.

Bull, I.D., Betancourt, P.P., Evershed, R.P., 1999a. Chemical evidence for a structured agricultural manuring regime on the island of Pseira, Crete during the Minoan Period, Aegaeum 20, 69-74.

Bull, I.D., Simpson, I.A., Dockrill, S.J., Evershed, R.P., 1999b. Organic geochemical evidence for the origin of ancient anthropogenic soil deposits at Tofts Ness, Sanday, Orkney. Organic Geochemistry 30, 535-556.

Bull, I.D., Simpson, I.A., Van Bergen, P.F., Evershed, R.P., 1999c. Muck 'n' molecules: Organic geochemical methods for detecting ancient manuring. Antiquity 73: 86-96.

Bull, I.D., van Bergen, P.F., Poulton, P.R., Evershed, R.P., 1998. Organic geochemical studies of soil from the Rothamsted Classical Experiments II, soils from Hoosfield Spring Barley experiment treated with different quantities of manure. Organic Geochemistry 28, 11-26.

Cappelen, J., 2014. Weather observations from Greenland 1958-2013. Observations data with description Technical report, No. 14-08, 24 pp. Danish Meteorological Institute, Copenhagen.

Charbonnier, P., 1999. Histoire de l'Auvergne des origines à nos jours: Haute et BasseAuvergne, Bourbonnais et Velay. Editions de Borée, 540pp.

Chassiot, L., Chapron, E., Di Giovanni, C., Lajeunesse, P., Tachikawa, K., Garcia, M., Bard, E., 2016. Historical seismicity of the Mont Dore volcanic province (Auvergne, France) unraveled by a regional lacustrine investigation: New insights about lake sensitivity to earthquakes. Sedimentary Geology 339, 134-150.

Chassiot, L., 2015. Forçages naturels et anthropiques sur la sédimentation holocène en domaine lacustre. Application aux lacs naturels d'Auvergne et aux réservoirs des bassins versants de la Loire et d'Adour-Garonne. PhD Thesis, Université d'Orléans, 500pp.

D’Anjou, R.M., Bradley, R.S., Balascio, N.L., Finkelstein, D.B., 2012. Climate impacts on human settlement and agricultural activities in northern Norway revealed through sediment biogeochemistry. Proceedings of the National Academy of Sciences 109, 20332-20337.

Dearing, J.A., Battarbee, R.W., Dikau, R., Larocque, I., Oldfield, F., 2006. Humanenvironment interactions: learning from the past. Regional Environmental Change6:1, 116.

Edvardsson, R., Paulsen, C., Church, M., Simpson, I., Adderly, P., Palsdottir, A., McGovern, T.H., 2007. Archaeological excavations at Qassiarsuk 2005 - 2006. Field and data structure report 03-07, $108 \mathrm{pp}$.

Elhmmali, M.M., Roberts, D.J., Evershed, R.P., 2000. Combined analysis of bile acids and sterols/stanols from riverine particulates to assess sewage discharges and other fecal sources. Environmental Science and Technology 34, 39-46.

Elhmmali, M.M., Roberts, D.J., Evershed, R.P., 1997. Bile acid as a new class of sewage pollution indicator. Environmental Science Technology 31, 3663-3668.

Ellis, E.C., Fuller, D.Q., Kaplan, J.O., Lutters, W.G., 2013. Dating the Anthropocene: Towards an empirical global history of human transformation of the terrestrial biosphere. Elementa: Science of the Anthropocene 1, 1-6. doi: 10.12952/journal.elementa.000018.

Evershed, R.P., Bethell, P.H., Reynolds, P.J., Walsh, N.J., 1997. 5 $\beta$-stigmastanol and related $5 \beta$-stanols as biomarkers of manuring: analysis of modern experimental material and assessment of the archaeological potential. Journal of Archaeological Science 24, 485-495.

Foley, J.A., Defries, R., Asner G.P., Barford, C., Bonan, G., 2005. Global consequences of land use. Science 309, 570-574.

Gaskell, S.J., Eglinton, G., 1974. Short-term diagenesis of sterols. In: Advances in organic geochemistry, 1973. Tissot, B., Bienner, F. (Eds), Rueil-Malmaison, France, 963-976.

Gauthier, E., Bichet, V., Massa, C., Petit, ., Vannière, B., Richard, H., 2010. Pollen and nonpollen palynomorph evidence of medieval farming activities in southwestern Greenland. Vegetation History and Archaeobotany 19, 427-438. 
Grimalt, J.O., Fernandez, P., Bayona, J.M., Albaiges, J., 1990. Assessment of fecal sterols and ketones as indicators of urban sewage inputs to coastal waters. Environmental Science Technology 24, 357-363.

Guillemot, T., Bichet, V., Gauthier, E., Zocatelli, R., Massa, C., Richard, H., 2016. Environmental responses of past and recent agropastoral activities on south Greenlandic ecosystems through molecular biomarkers. The Holocene 27:6, 1-13.

Guillemot, T., Zocatelli, R., Bichet, V., Jacob, J., Gauthier, E., Massa, C., Le Milbeau, C., Richard, H., 2015.Evolution of pastoralism in Southern Greenland during the last two millennia reconstructed from bile acids and coprophilous fungal spores in lacustrine sediments. Organic Geochemistry 81, 40-44.

Hurtt, G.C., Frolking, S., Fearon, M.G., Moore, B., Shevliakova, E., Malyshev, S;, Pacala S.W., Houghton, R.A., 2006. The underpinnings of land-use history: three centuries of global gridded land-use transitions, wood harvest activity, and resulting secondary lands. Global Change Biology 12, 1208-1229.

IPCC 2013. Climate Change 2013: The Physical Science Basis: A Report of Working Group I of the Intergovernmental Panel on Climate Change. IPCC.

Jacob, J., Disnar, J.-R., Arnaud, F., Gauthier, E., Billaud, Y., Chapron, E., Bardoux, G., 2009. Impacts of new agricultural practices on soil erosion during the Bronze Age in the French Prealps. The Holocene 19, 241-249.

Jacob, J., Disnar, J-R., Arnaud, F., Chapron, E., Debret, M., Lallier-Vergès, E., Desmet, M., Revel-Rolland, M., 2008. Millet cultivation history in the French Alps as evidenced by a sedimentary molecule. Journal of Archaeological Sciences 35, 814-820.

Jardé, E., Gruau, G., Mansuy-Huault, L., 2007a. Detection of manure-derived organic compounds in rivers draining agricultural areas of intensive manure spreading. Applied Geochemistry 22, 1814-1824.

Jardé, E., Gruau, G., Mansuy-Huault, L., Peu, P., Martinez, J., 2007b. Using sterols to detect pig slurry contribution to soil organic matter. Water, Air and Soil Pollution 178, 169-178.

Joyeux, P., 2013. Mémoire de fouilles : Une nouvelle Orléans, Des secrets bien enfouis sous la 2de ligne de tramway. INRAP, Institut national de recherches archéologiques préventives. 40pp.

Killops, S.D., Killops, V.J., 2004. An Introduction to Organic Geochemistry, second ed. Blackwell Publishing, Oxford, 408 pp.

Lavrieux, M., Jacob, J., Disnar, J.-R., Bréheret, J.-G., Le Milbeau, C., Miras, Y., AndrieuPonel, V., 2013a. Sedimentary cannabinol tracks the history of hemp retting. Geology 41, 751-754.

Lavrieux, M.L., Bréheret, J.G., Disnar, J.-R., Jacob, J., Le Milbeau, C., Zocatelli, R., 2012. Preservation of an ancient grassland biomarker signature in a forest soil from the French Massif Central. Organic Geochemistry 51, 1-10.

Lavrieux, M., Jacob, J., Le Milbeau, C., Zocatelli, R., Masuda, K., Bréheret, J.G., Disnar, J.R., 2011. Occurrence of triterpenyl acetates in soil and their potential as chemotaxonomical biomarkers of Asteraceae. Organic Geochemistry 42, 1315-1323.

Leeming, R., Ball, A., Ashbolt, N., Nichols., P., 1996. Using fecal sterols from humans and animals to distinguish fecal pollution in receiving waters. Water Research 30, 2893-2900.

Madsen, C.K., 2014. Pastoral settlement, farming and hierarchy in Norse Vatnahverfi, South Greenland. PhD Thesis, University of Copenhagen, 440 pp.

Massa, C., Bichet, V., Gauthier, E., Perren, B.B., Mathieu, O., Petit, C., Monna, F., Giraudeau, J., Losno, R., Richard, H., 2012. A 2500 year record of natural and anthropogenic soil erosion in South Greenland. Quaternary Science Reviews 32, 119-130.

McGovern, T.H., 1983. The zooarcheology of Ø17a. Meddelelsero Grønland Man and Society $18,58-74$. 
Mermoud, F., Wunsche, L., Clerc, O., Gulacar, F.O. \& Buchs, A., 1984. Steroidal ketones in the early diagenetic transformations of $\Delta^{5}$ sterols in different types of sediments. Organic Geochemistry 6, 25-29.

Nes, W.R., Nes, W.D., 1980. Lipids in evolution. New York: Plenum Press, 244pp.

510

Oldfield, F., Wake, R., Boyle, J., Jones, R., Nolan, S., Gibbs, Z., Appleby, P., Fisher, E., Wolff, G., 2003. The late-Holocene history of Gormire Lake (NE England) and its catchment: a multiproxy reconstruction of past human impact. The Holocene 13, 677-690.

Pepe, C., Dizabo, P., 1990. Étude d'une fosse du 13 ${ }^{\text {ème }}$ siècle par les marqueurs biogéochimiques: chantier archéologique du Louvre (Paris). Revue d'Archéométrie 14, $23-$ 28.

Redman, C.L., 1999. Human Impact on Ancient Environments. University of Arizona Press, Tucson, 288pp.

Ruddiman, W.F., 2013. The Anthropocene. Annual Review of Earth and Planetary Sciences 41, 45-68.

Ruddiman, W.F., 2003. The Anthropogenic greenhouse era began thousands of years ago. Climate Change 61, 261-293. (doi:10.1023/B:CLIM.0000004577.17928.fa)

Rushdi, A.I., Douabul, A.A., Mohammed, S.S., Simoneit, B.R.T., 2006. Compositions and sources of extractable organic matter in Mesopotamian marshland surface sediments of Iraq: II. Polar compounds. Environmental Geology 50, 1171-1181.

Shillito, L-M., Bull, I.D., Matthew, W., Almond, M.A., Williams, J.M., Evershed, R.P., 2011a. Biomolecular and micromorphological analysis of suspected fecal deposits at Neolithic Çatalhöyük, Turkey. Journal of Archaeological Science 38, 1869-1877.

Shillito, L.-M., Matthews, W., Almond, M.J., Bull, I.D., 2011b. The microstratigraphy of middens: capturing daily routine in rubbish at Neolithic Çatalhöyük, Turkey. Antiquity 85, 1024-1038.

Simoneit, B.R.T., 2002. Molecular indicators (biomarkers) of past life. The Anatomical Record 268, 186-195.

Simpson, I.A., Bull, I.D., Dockrill, S.J., Evershed, R.P., 1998. Early anthropogenic soil formation at Tofts Ness, Sanday, Orkney. Journal of Archaeological Science 25, 729-746.

Smith, B.D., Zeder, M.A., 2013. The onset of the Anthropocene. Anthropocene, http://dx.doi.org/10.1016/j.ancene.2013.05.001.

Syvitski, J.P.M., Kettner, A. 2011. Sediment flux and the Anthropocene. Philosophical Transactions of the Royal Society A: Mathematical, Physical and Engineering Sciences 369, 957-975.

Syvitski, J.P.M., Kettner, A., Peckham, S.D., Kao, S.J. 2005. Predicting the flux of sediment to the coastal zone: application to the Lanyang watershed, northern Taiwan. J. Coast. Res. 21, 580-587. (doi:10.2112/04-702A.1).

Tyagi, P., Edwards, D.R., Coyne, M.S., 2008. Use of Sterol and Bile Acid Biomarkers to Identify Domesticated Animal Sources of Fecal Pollution. Water Air Soil Pollution 187, 263-274.

van Bergen, P., Bull, I., Poulton, P.R., Evershed, R.P., 1997. Organic geochemical studies of soils from the Rothamsted Classical Experiments - 1. Total lipid extracts, solvent insoluble residues and humic acids from Broadbalk Wilderness. Organic Geochemistry 26, 117-135.

Zeder, M.A., Bradley, D.G., Emshwiller, E., Smith, B.D. (Eds.), 2006. Documenting Domestication: New Genetic and Archaeological Paradigms. University of California Press, Berkeley.

Zocatelli, R., Moreira-Turcq, P., Bernardes, M., Turcq, B., Cordeiro, R.C., Gogo, S., Disnar, J.-R., Boussafir, M., 2013. Sedimentary evidence of soil organic matter input to the Curuai Amazonian floodplain. Organic Geochemistry 63, 40-47.

Zocatelli, R., Lavrieux, M., Disnar, J.-R., Le Milbeau, C., Jacob, J., Bréheret, J.-G., 2012. Free fatty acids in Lake Aydat catchment soils (French Massif Central): sources, distributions and potential use as sediment biomarkers. Journal of Soils and Sediments 12, 734-748. 
Zocatelli, R., Jacob, J., Turcq, B., Boussafir, M., Sifeddine, A., Bernardes, M.C., 2010. Molecular evidence for recent turf cultivation in Northeast Brazil (Lagoa do Boqueirão, RN State). Organic Geochemistry 41, 427-430.

Zolitschka, B. and Ariztegui, D., 2007. Lacustrine and marine archives of environmental variability across South America. Quaternary International 161, 1-3.

\section{TABLE CAPTIONS}

Table 1: Sterol and bile acids contents $(\mu \mathrm{g} / \mathrm{g})$ and ratios of fecal sterols for reference samples. Values of Sr1 > 0.7 indicate fecal material detection (Grimalt et al., 1990). Values of Sr2 > 1 indicate the predominance of herbivorous feces (Bull et al., 2002). Cp: coprostanol, epi-Cp: epi-coprostanol, Chl: cholesterol, Chln: cholestanol, mCp: methyl-coprostanol, ethCp: ethylcoprostanol, Sit: sitosterol, ethChln: ethyl-cholestanol, LC: lithocholic acid, DOC: deoxycholic acid, CDOC: chenodeoxycholic acid, C: cholic acid, HDOC: hyodeoxycholic acid and UDOC: ursodeoxycholic acid.

Table 2: Sterol and bile acids contents ( $\mathrm{mg} / \mathrm{g}$ and $\mu \mathrm{g} / \mathrm{g}$, respectively) and ratios of fecal sterols for the samples. Values of $\mathrm{Sr} 1>0.7$ indicate feces samples. Values of $\mathrm{Sr} 2>1$ indicate the predominance of herbivorous feces (Bull et al., 2002). Cp: coprostanol, epi-Cp: epicoprostanol, Chl: cholesterol, Chln: cholestanol, mCp: methyl-coprostanol, ethCp: ethylcoprostanol, Sit: sitosterol, ethChln: ethyl-cholestanol, LC: lithocholic acid, DOC: deoxycholic acid, CDOC: chenodeoxycholic acid, C: cholic acid, HDOC: hyodeoxycholic acid and UDOC: ursodeoxycholic acid.

\section{FIGURE CAPTIONS}

Fig. 1: Location of study sites: In Greenland (a), Igaliku catchment (b; dotted line, LI - Lake Igaliku), Orléans archaeological site and Massif Central(c) with, for the latter the Aydat catchment (dotted line, d; LA - Lake Aydat) and theMontcineyre catchment (dotted line, e; LM - Lake Montcineyre).

Fig.2: Distribution of sterols and bile acids in animal fecal materials in reference samples (a, b, e and f). Note the different scales used between sterols and bile acids, and between herbivorous and omnivorous fecal biomarkers. Example of total ion current (TIC) chromatogram of sheep (c and $\mathrm{d}$ ) and human ( $\mathrm{g}$ and $\mathrm{h}$ ) feces. For the nomenclature of compounds refer to Section 3.1.

Fig. 3: Distribution of sterols (a) and bile acids (b) in a septic tank active during the $19^{\text {th }}$ century (St19) and in the layers of a midden from a building dating from the Middle Ageswith unknown 
594 occupation $\left(16^{\text {th }}, 15^{\text {th }}\right.$ and $14^{\text {th }}$ centuries). Specific ion mass $(\mathrm{m} / \mathrm{z})$ chromatograms of alcohol 595 fraction $(\mathrm{m} / \mathrm{Z}=215+255+213+368+383+398+484)$ and acidic fraction $(\mathrm{m} / \mathrm{Z}=$ $596208+215+253+255+368)$ from sample S16 (c, d). Cp/epi-Cp and DOC/C ratios from human 597 fecal material, septic tank and middenlayers samples (e). For the nomenclature of compounds $598 \quad$ refer to Section 3.1.

599

600 Fig. 4: Relative average concentrations of sterols and bile acids in soil lipid extracts (a,b). GC-

601 MS chromatograms (TIC) of sample PS8 for alcohol and acidic fractions (c,d). Nomenclature

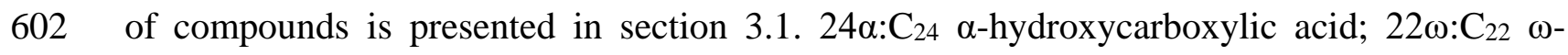

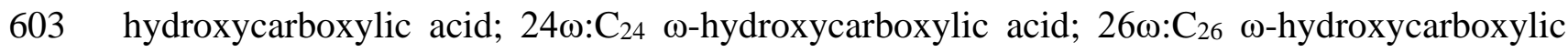
604 acid; $\mathrm{C}_{30}-\mathrm{OH}: \mathrm{C} 30$ n-alkanol; $\mathrm{C}_{32}-\mathrm{OH}: \mathrm{C}_{32 n}$-alkanol.

605

606 Fig.5: Evolution of Total Coprostanols (Cp + epi-Cp + mCp + epi-ethCp +ethCp), Sr2 ratio, 607 LC and DOC contents in lacustrine sediments (a). Specific ion mass ( $\mathrm{m} / \mathrm{Z}$ ) chromatograms of 608 alcohol fraction $(\mathrm{m} / \mathrm{Z}=215+255+213+368+383+398+484)$ and acidic fraction $(\mathrm{m} / \mathrm{Z}=$ $609208+215+253+255+368)$ of sampleMO-1are shown $(b, c)$. Nomenclature of compounds is 610 presented in section 3.1 .

611

612 Fig.6: Evolution of Total Coprostanols ( $\mathrm{Cp}+$ epi-Cp $+\mathrm{mCp}+$ epi-ethCp +ethCp), $\mathrm{Sr} 2$ ratio 613 and DOC contents over the last two millennia in lacustrine sediments (a). Specific ion mass $614(\mathrm{~m} / \mathrm{Z})$ chromatograms of alcohol fraction $(\mathrm{m} / \mathrm{z}=215+255+213+368+383+398+484)$ and acidic 615 fraction $(\mathrm{m} / \mathrm{Z}=208+215+253+255+368)$ of sample IGA-82 are shown $(\mathrm{b}, \mathrm{c})$. Nomenclatures of 616 compounds are given in section 3.1.

617

618

619

620

621

622

623

624 
Fig.1

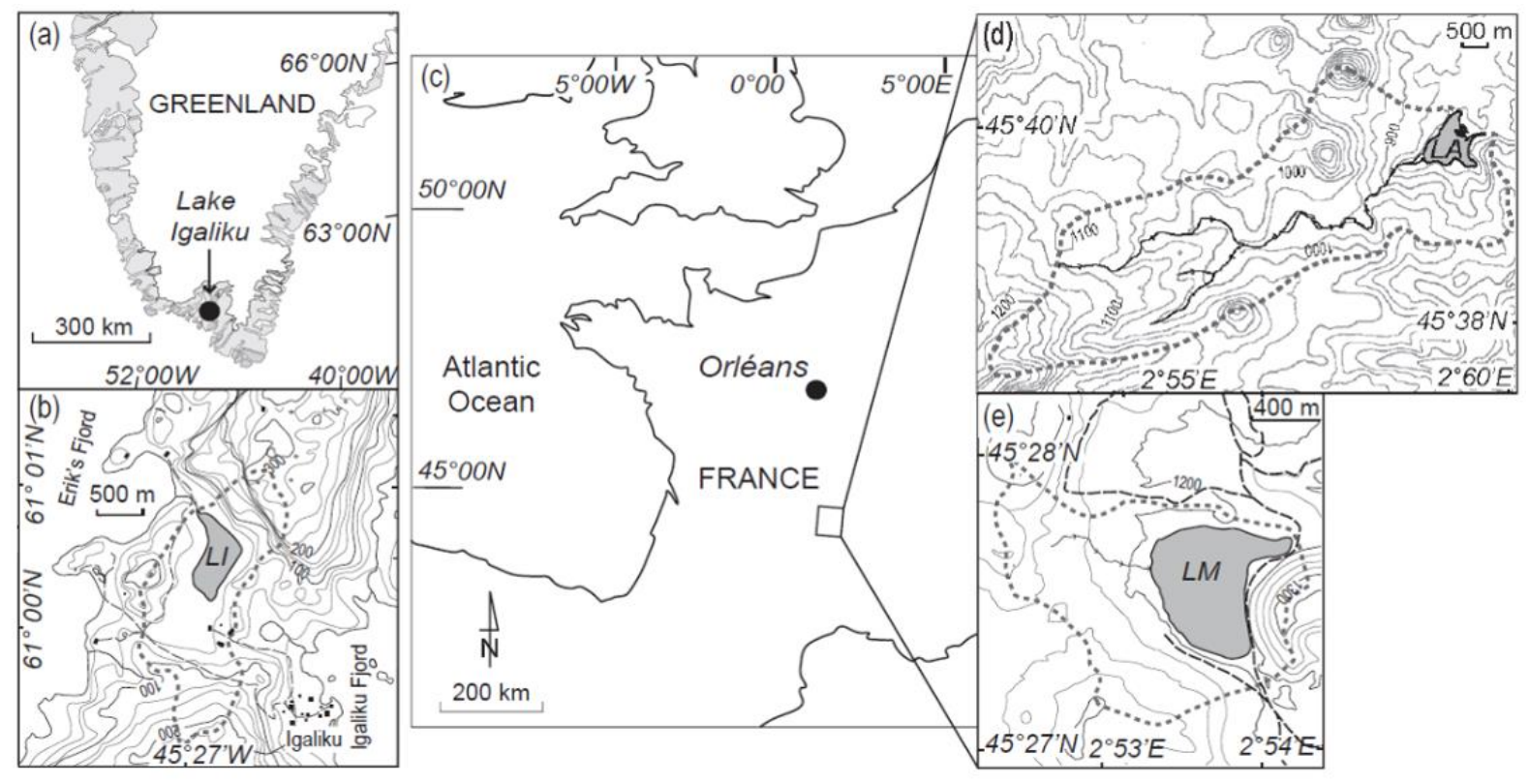

628 Fig.2

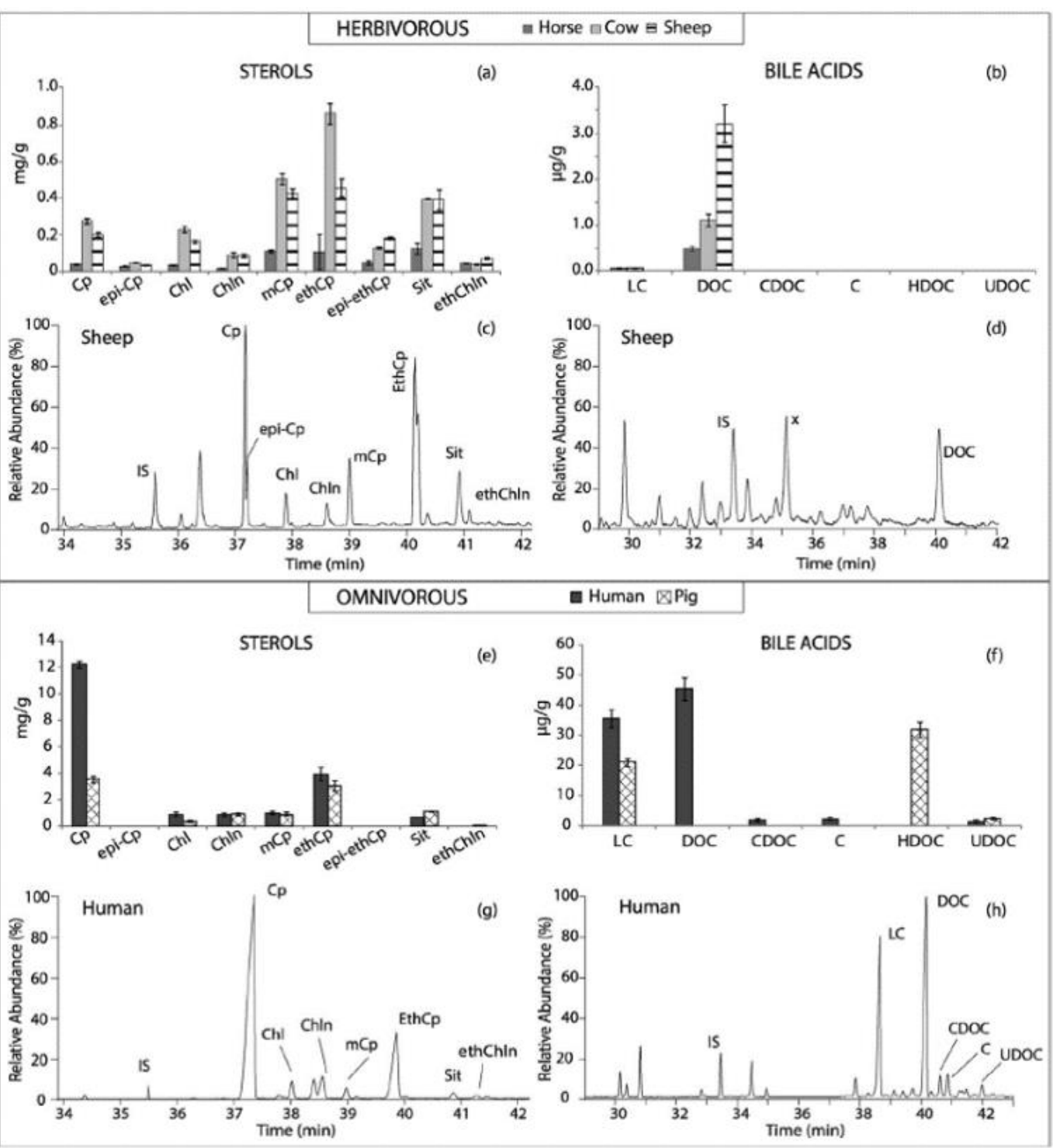


Fig. 3

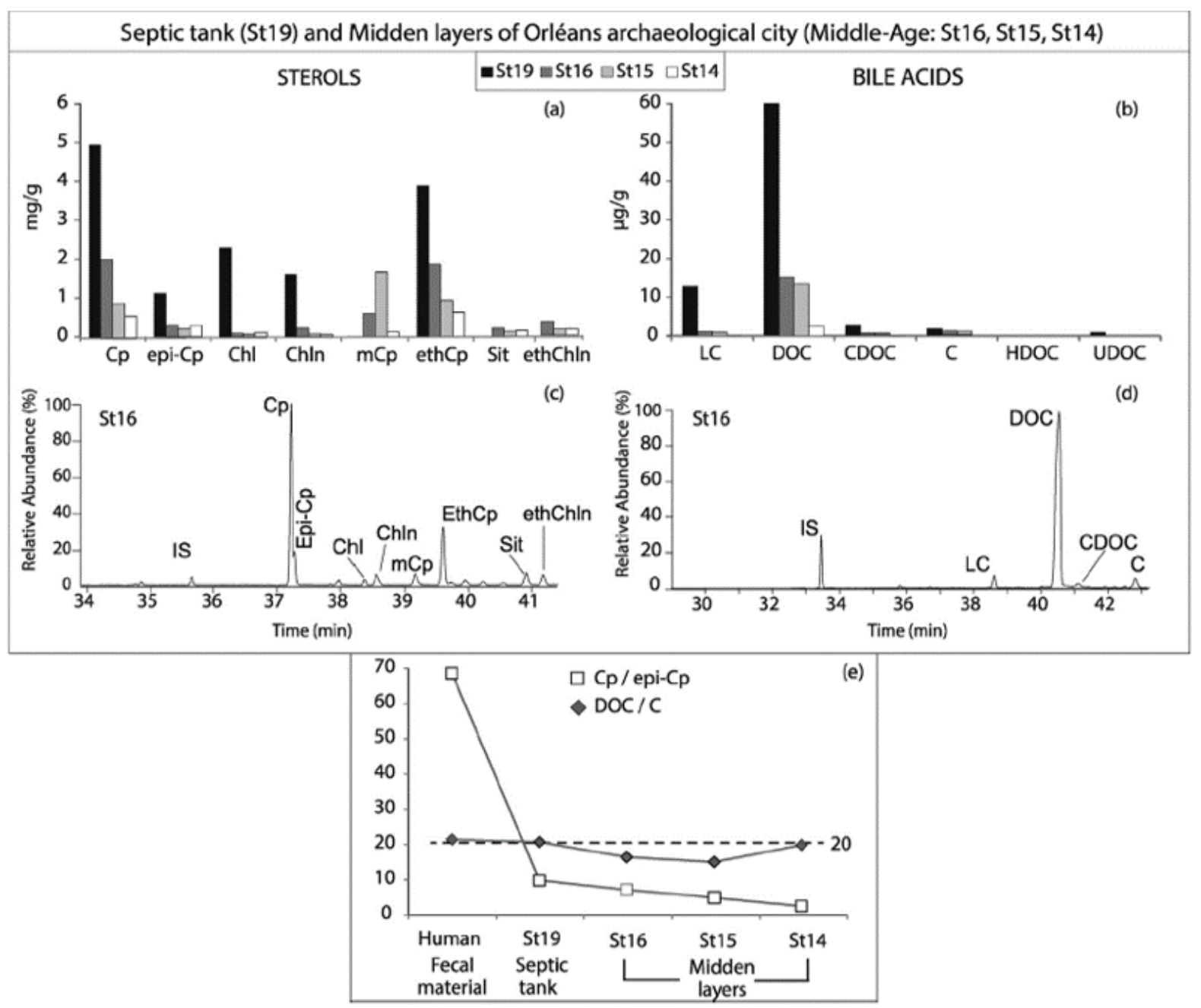

631

632 Fig. 4

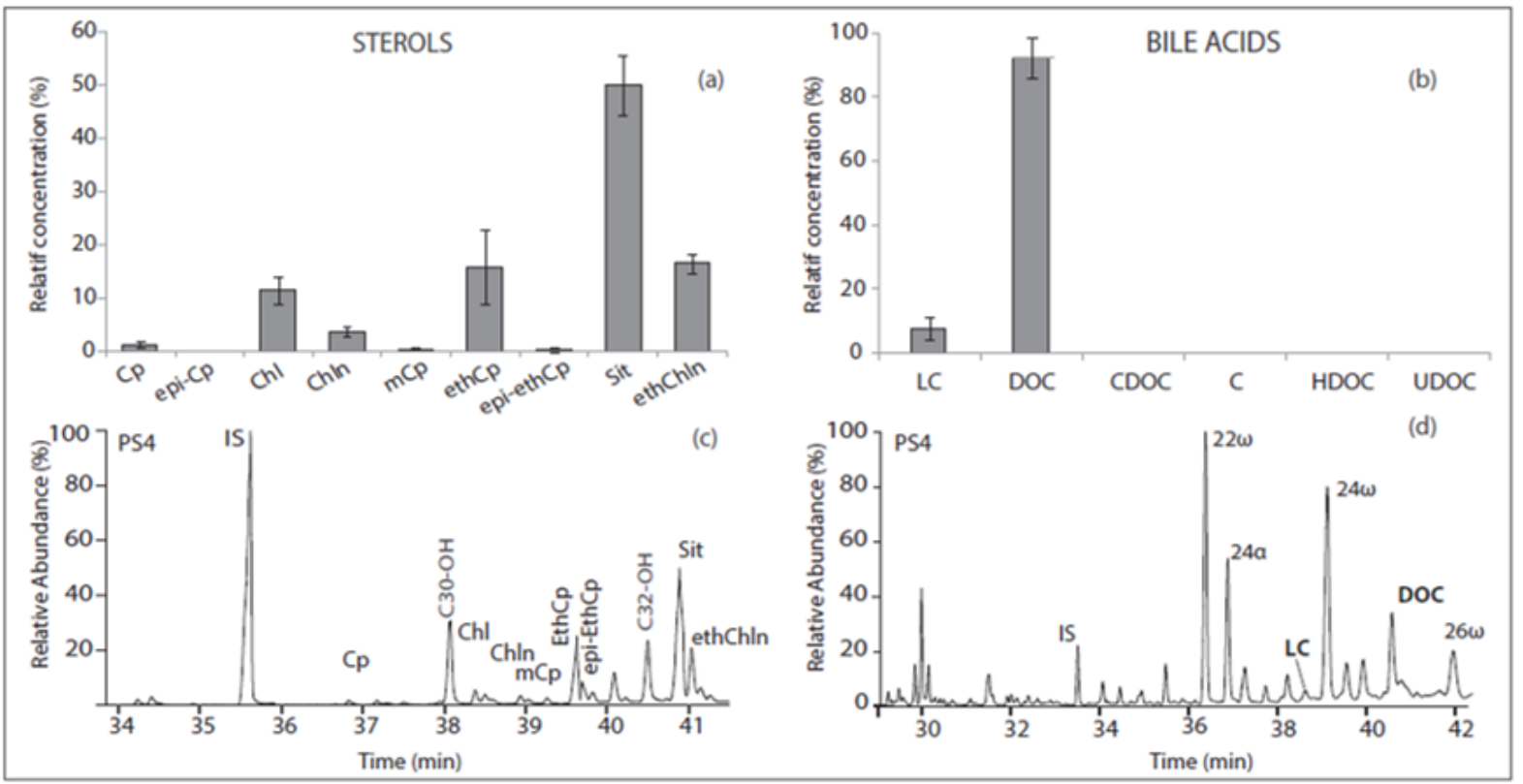


Fig. 5

636

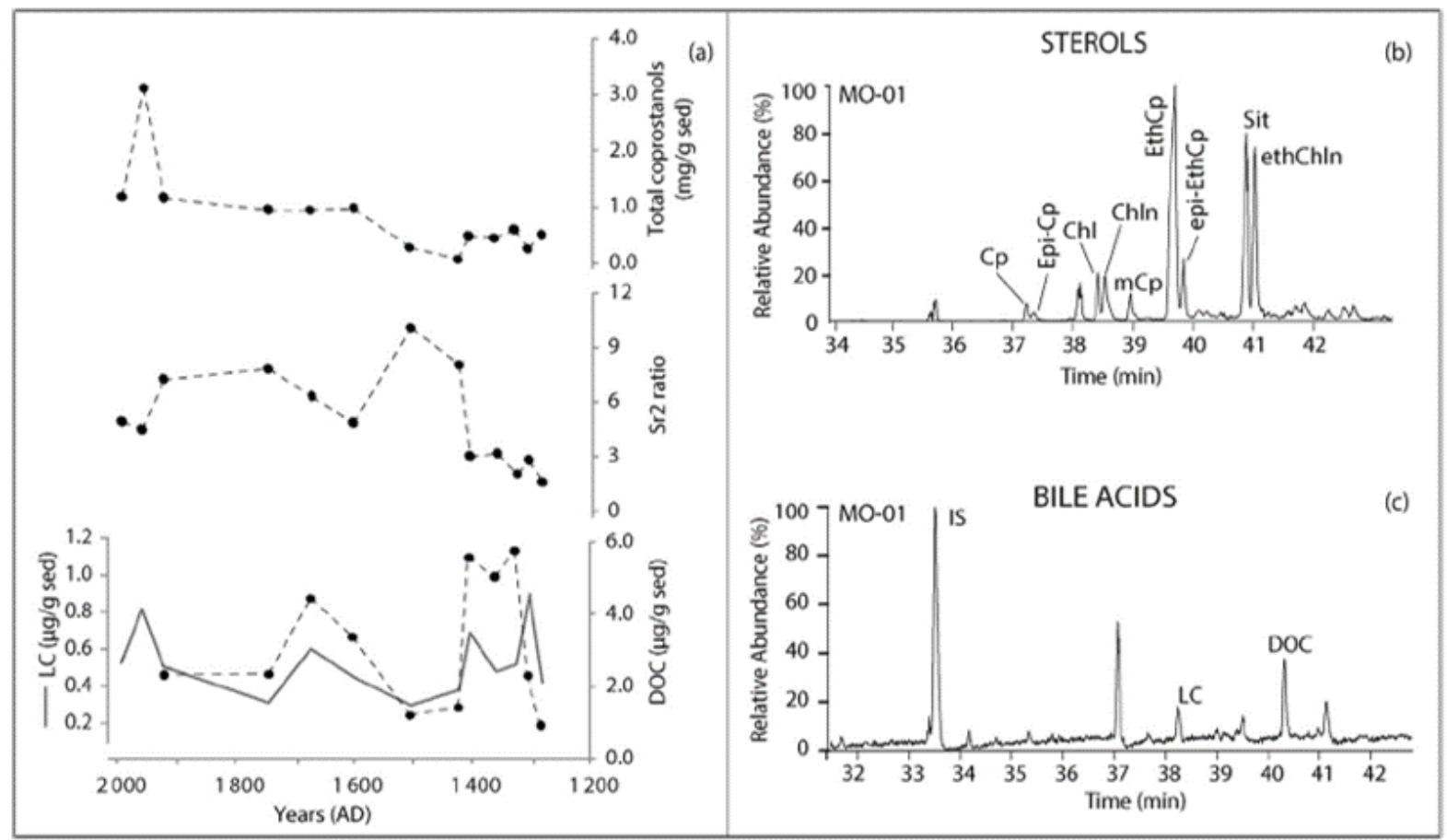

637 Fig. 6

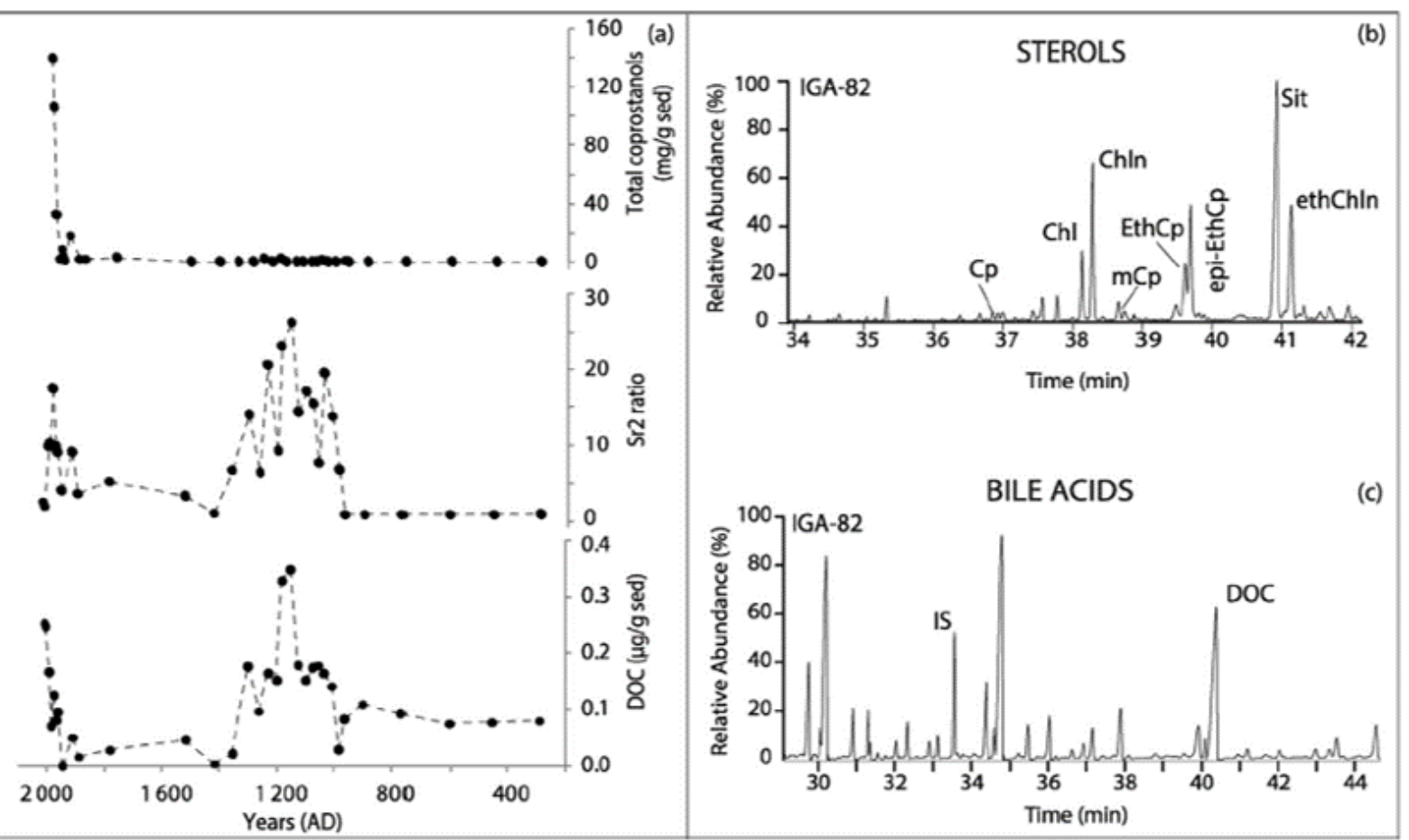


643 Table 1:

\begin{tabular}{llllll}
\hline & Horse & Cow & Sheep & Human & Pig \\
\hline Sterols & & & & & \\
Cp & 40 & 275 & 203 & 12251 & 3552 \\
epi-Cp & 29 & 49 & 36 & 0 & 0 \\
Chl & 36 & 230 & 164 & 866 & 376 \\
Chln & 17 & 90 & 87 & 857 & 941 \\
mCp & 110 & 506 & 425 & 980 & 888 \\
ethCp & 109 & 859 & 456 & 3929 & 3093 \\
epi-ethCp & 48 & 128 & 182 & 0 & 0 \\
Sit & 124 & 395 & 392 & 707 & 1102 \\
ethChln & 44 & 40 & 72 & 0 & 80 \\
Total Coprostanols & 336 & 1817 & 1302 & 17160 & 7533 \\
\% coprostanols & 60.33 & 70.64 & 64.55 & 87.70 & 76.29 \\
Sr1 & 0.70 & 0.75 & 0.70 & 0.93 & 0.79 \\
Sr2 & 2.29 & 3.05 & 2.67 & 0.32 & 0.76 \\
Bile Acids & & & & & \\
LC & 0.07 & 0.07 & 0.00 & 35.56 & 21.07 \\
DOC & 0.48 & 1.10 & 3.21 & 45.44 & nd \\
CDOC & nd & nd & nd & 2.15 & nd \\
C & nd & nd & nd & 1.79 & nd \\
HDOC & nd & nd & nd & nd & 32.01 \\
UDOC & nd & nd & nd & 1.24 & 2.31 \\
Total Bile Acids & 0.56 & 1.17 & 3.21 & 86.18 & 55.38 \\
\hline
\end{tabular}

644

645

646

647

648

649

650

651

652

653

654

655 


\begin{tabular}{|c|c|c|c|c|c|c|c|c|c|c|c|c|c|c|c|c|c|c|c|}
\hline & $\mathrm{Cp}$ & epi-Cp & Chl & Chln & $\mathrm{mCp}$ & ethCp & $\begin{array}{l}\text { epi- } \\
\text { ethCp }\end{array}$ & Sit & ethChln & $\begin{array}{l}\text { Total } \\
\text { Coprostanols }\end{array}$ & $\begin{array}{l}\text { Coprostanols } \\
(\%)\end{array}$ & Sr1 & $\mathrm{Sr} 2$ & $\mathrm{LC}$ & $\mathrm{DOC}$ & $\mathrm{CDOC}$ & $\mathrm{C}$ & HDOC & UDOC \\
\hline St19 & 10.54 & 1.12 & 2.29 & 1.61 & 0.00 & 3.89 & 0.00 & 0.00 & 0.00 & 15.55 & 79.98 & 0.88 & 0.33 & 12.85 & 60.12 & 0.00 & 2.95 & 0.00 & 0.10 \\
\hline St16 & 2.04 & 0.31 & 0.09 & 0.22 & 0.60 & 1.86 & 0.00 & 0.22 & 0.34 & 4.80 & 84.62 & 0.91 & 0.79 & 1.19 & 15.30 & 0.18 & 0.95 & 0.00 & 0.00 \\
\hline St15 & 0.91 & 0.20 & 0.06 & 0.08 & 0.55 & 0.94 & 0.00 & 0.14 & 0.15 & 2.60 & 85.80 & 0.94 & 0.84 & 1.03 & 13.45 & 0.17 & 0.92 & 0.00 & 0.00 \\
\hline St14 & 0.80 & 0.07 & 0.10 & 0.05 & 0.12 & 0.63 & 0.00 & 0.16 & 0.16 & 1.62 & 77.62 & 0.94 & 0.73 & 0.17 & 2.64 & 0.02 & 0.14 & 0.00 & 0.00 \\
\hline PS1 & 0.23 & 0.00 & 3.77 & 0.94 & 0.04 & 4.13 & 0.25 & 16.99 & 5.66 & 4.65 & 14.54 & 0.20 & 19.06 & 0.08 & 0.84 & 0.00 & 0.00 & 0.00 & 0.00 \\
\hline PS2 & 0.27 & 0.00 & 2.66 & 1.02 & 0.12 & 2.98 & 0.28 & 15.34 & 5.11 & 3.64 & 13.12 & 0.21 & 11.97 & 0.12 & 1.44 & 0.00 & 0.00 & 0.00 & 0.00 \\
\hline PS3 & 0.50 & 0.00 & 7.08 & 1.54 & 0.00 & 3.57 & 0.37 & 29.84 & 9.95 & 4.44 & 8.40 & 0.24 & 7.93 & 0.13 & 1.47 & 0.00 & 0.00 & 0.00 & 0.00 \\
\hline PS4 & 0.15 & 0.00 & 3.59 & 0.87 & 0.00 & 2.67 & 0.00 & 20.94 & 6.98 & 2.83 & 8.03 & 0.15 & 17.41 & 0.18 & 2.24 & 0.00 & 0.00 & 0.00 & 0.00 \\
\hline PS5 & 1.60 & 0.00 & 7.14 & 4.27 & 0.46 & 24.84 & 0.00 & 25.63 & 8.54 & 26.90 & 37.11 & 0.27 & 15.55 & 0.24 & 3.07 & 0.00 & 0.00 & 0.00 & 0.00 \\
\hline PS6 & 0.19 & 0.00 & 1.03 & 0.56 & 0.00 & 1.96 & 0.00 & 6.23 & 2.08 & 2.15 & 17.84 & 0.26 & 10.24 & 0.26 & 3.34 & 0.00 & 0.00 & 0.00 & 0.00 \\
\hline PS7 & 0.11 & 0.00 & 2.55 & 0.54 & 0.00 & 1.02 & 0.00 & 7.41 & 2.47 & 1.13 & 8.00 & 0.16 & 9.71 & 0.33 & 3.71 & 0.00 & 0.00 & 0.00 & 0.00 \\
\hline PS8 & 0.06 & 0.00 & 0.29 & 0.06 & 0.02 & 0.47 & 0.01 & 0.84 & 0.28 & 0.56 & 27.62 & 0.51 & 7.64 & 0.36 & 4.05 & 0.00 & 0.00 & 0.00 & 0.00 \\
\hline PS9 & 0.28 & 0.00 & 2.22 & 1.00 & 0.20 & 2.61 & 0.00 & 8.21 & 2.74 & 3.09 & 17.90 & 0.22 & 9.34 & 0.35 & 4.10 & 0.00 & 0.00 & 0.00 & 0.00 \\
\hline PS10 & 1.06 & 0.00 & 3.30 & 2.17 & 0.29 & 13.72 & 0.00 & 26.06 & 8.69 & 15.07 & 27.25 & 0.33 & 12.98 & 0.33 & 4.25 & 0.00 & 0.00 & 0.00 & 0.00 \\
\hline MO-0 & 0.11 & 0.08 & 8.88 & 1.40 & 0.06 & 0.81 & 0.13 & 14.05 & 5.19 & 1.19 & 3.88 & 0.12 & 4.92 & 0.53 & 5.05 & 0.00 & 0.00 & 0.00 & 0.00 \\
\hline MO-1 & 0.32 & 0.22 & 17.43 & 3.34 & 0.16 & 2.09 & 0.34 & 21.29 & 6.68 & 3.13 & 6.04 & 0.14 & 4.47 & 0.81 & 5.27 & 0.00 & 0.00 & 0.00 & 0.00 \\
\hline MO-2 & 0.09 & 0.05 & 7.75 & 1.20 & 0.06 & 0.83 & 0.13 & 13.91 & 4.84 & 1.16 & 4.01 & 0.10 & 7.22 & 0.51 & 2.33 & 0.00 & 0.00 & 0.00 & 0.00 \\
\hline MO-7 & 0.06 & 0.04 & 1.87 & 0.47 & 0.09 & 0.65 & 0.11 & 7.98 & 5.02 & 0.94 & 5.79 & 0.17 & 7.84 & 0.31 & 2.36 & 0.00 & 0.00 & 0.00 & 0.00 \\
\hline MO-9 & 0.06 & 0.05 & 2.43 & 0.45 & 0.15 & 0.59 & 0.10 & 15.69 & 11.58 & 0.95 & 3.06 & 0.19 & 6.31 & 0.60 & 4.45 & 0.00 & 0.00 & 0.00 & 0.00 \\
\hline MO-11 & 0.07 & 0.06 & 4.32 & 0.55 & 0.21 & 0.54 & 0.08 & 12.36 & 8.83 & 0.96 & 3.56 & 0.19 & 4.83 & 0.45 & 3.38 & 0.00 & 0.00 & 0.00 & 0.00 \\
\hline MO-14 & 0.01 & 0.01 & 0.81 & 0.08 & 0.02 & 0.21 & 0.03 & 2.95 & 2.24 & 0.29 & 4.53 & 0.24 & 10.11 & 0.30 & 1.21 & 0.00 & 0.00 & 0.00 & 0.00 \\
\hline MO-17 & 0.00 & 0.00 & 0.03 & 0.01 & 0.00 & 0.06 & 0.01 & 0.63 & 0.27 & 0.08 & 7.90 & 0.44 & 8.13 & 0.38 & 1.43 & 0.00 & 0.00 & 0.00 & 0.00 \\
\hline MO-25 & 0.02 & 0.04 & 1.58 & 0.35 & 0.20 & 0.16 & 0.04 & 6.51 & 3.32 & 0.46 & 3.80 & 0.16 & 3.02 & 0.69 & 5.59 & 0.00 & 0.00 & 0.00 & 0.00 \\
\hline MO-45 & 0.03 & 0.03 & 1.61 & 0.40 & 0.22 & 0.15 & 0.03 & 5.90 & 4.57 & 0.45 & 3.51 & 0.12 & 3.17 & 0.48 & 5.06 & 0.00 & 0.00 & 0.00 & 0.00 \\
\hline
\end{tabular}




\begin{tabular}{|c|c|c|c|c|c|c|c|c|c|c|c|c|c|c|c|c|c|c|c|}
\hline MO-60 & 0.03 & 0.05 & 1.81 & 0.45 & 0.35 & 0.14 & 0.02 & 6.73 & 2.25 & 0.58 & 4.94 & 0.15 & 2.09 & 0.52 & 5.77 & 0.00 & 0.00 & 0.00 & 0.00 \\
\hline MO-70 & 0.02 & 0.02 & 0.98 & 0.25 & 0.10 & 0.10 & 0.02 & 6.90 & 1.95 & 0.26 & 2.55 & 0.15 & 2.77 & 0.89 & 2.32 & 0.00 & 0.00 & 0.00 & 0.00 \\
\hline MO-80 & 0.04 & 0.06 & 1.62 & 0.37 & 0.21 & 0.15 & 0.02 & 6.61 & 1.64 & 0.48 & 4.50 & 0.22 & 1.61 & 0.42 & 0.94 & 0.00 & 0.00 & 0.00 & 0.00 \\
\hline IGA-01 & 38.61 & 0.00 & 154.59 & 130.56 & 0.00 & 100.60 & 0.00 & 89.55 & 14.92 & 139.20 & 26.32 & 0.23 & 2.61 & 0.00 & 0.25 & 0.00 & 0.00 & 0.00 & 0.00 \\
\hline IGA-03 & 34.87 & 0.00 & 103.57 & 106.38 & 0.00 & 71.71 & 0.00 & 75.08 & 12.51 & 106.58 & 26.37 & 0.25 & 2.06 & 0.00 & 0.25 & 0.00 & 0.00 & 0.00 & 0.00 \\
\hline IGA-07 & 3.04 & 0.00 & 53.52 & 57.13 & & 29.63 & 0.00 & 66.45 & 11.07 & 32.67 & 14.79 & 0.05 & 9.75 & 0.00 & 0.17 & 0.00 & 0.00 & 0.00 & 0.00 \\
\hline IGA-09 & 0.23 & 0.00 & 2.91 & 3.81 & 0.00 & 2.41 & 0.00 & 4.06 & 0.68 & 2.64 & 18.73 & 0.06 & 10.42 & 0.00 & 0.07 & 0.00 & 0.00 & 0.00 & 0.00 \\
\hline IGA-11 & 0.50 & 0.00 & 12.23 & 11.55 & 0.00 & 8.64 & 0.00 & 12.86 & 2.14 & 9.14 & 19.07 & 0.04 & 17.44 & 0.00 & 0.13 & 0.00 & 0.00 & 0.00 & 0.00 \\
\hline IGA-12 & 0.28 & 0.00 & 3.52 & 6.36 & 0.00 & 2.71 & 0.00 & 3.47 & 0.58 & 2.98 & 17.63 & 0.04 & 9.79 & 0.00 & 0.08 & 0.00 & 0.00 & 0.00 & 0.00 \\
\hline IGA-13 & 0.14 & 0.00 & 1.56 & 2.84 & 0.00 & 1.31 & 0.00 & 2.45 & 0.41 & 1.45 & 16.66 & 0.05 & 9.09 & 0.00 & 0.09 & 0.00 & 0.00 & 0.00 & 0.00 \\
\hline IGA-15 & 3.73 & 0.00 & 27.75 & 53.70 & 0.00 & 14.88 & 0.00 & 33.49 & 5.49 & 18.61 & 13.39 & 0.07 & 3.98 & 0.00 & 0.00 & 0.00 & 0.00 & 0.00 & 0.00 \\
\hline IGA-19 & 0.28 & 0.00 & 5.74 & 7.74 & 0.00 & 1.02 & 1.50 & 4.76 & 0.77 & 2.80 & 12.86 & 0.03 & 9.08 & 0.00 & 0.05 & 0.00 & 0.00 & 0.00 & 0.00 \\
\hline IGA-21 & 0.60 & 0.00 & 12.20 & 12.69 & 0.00 & 0.91 & 1.30 & 15.19 & 2.47 & 2.81 & 6.19 & 0.05 & 3.69 & 0.00 & 0.02 & 0.00 & 0.00 & 0.00 & 0.00 \\
\hline IGA-29 & 0.51 & 0.00 & 6.44 & 6.48 & 0.00 & 1.22 & 1.50 & 5.34 & 0.87 & 3.23 & 14.46 & 0.07 & 5.30 & 0.00 & 0.03 & 0.00 & 0.00 & 0.00 & 0.00 \\
\hline IGA-45 & 0.01 & 0.00 & 0.05 & 0.05 & 0.00 & 0.01 & 0.02 & 0.05 & 0.01 & 0.04 & 20.08 & 0.16 & 3.22 & 0.00 & 0.05 & 0.00 & 0.00 & 0.00 & 0.00 \\
\hline IGA-52 & 0.01 & 0.00 & 0.03 & 0.02 & 0.00 & 0.00 & 0.01 & 0.02 & 0.00 & 0.02 & 26.27 & 0.40 & 1.13 & 0.00 & 0.00 & 0.00 & 0.00 & 0.00 & 0.00 \\
\hline IGA-57 & 0.01 & 0.00 & 0.15 & 0.14 & 0.00 & 0.02 & 0.03 & 0.13 & 0.02 & 0.07 & 13.00 & 0.06 & 6.79 & 0.00 & 0.02 & 0.00 & 0.00 & 0.00 & 0.00 \\
\hline IGA-62 & 0.02 & 0.00 & 0.31 & 0.34 & 0.00 & 0.12 & 0.15 & 0.43 & 0.07 & 0.29 & 20.09 & 0.05 & 13.96 & 0.00 & 0.18 & 0.00 & 0.00 & 0.00 & 0.00 \\
\hline IGA-66 & 0.30 & 0.00 & 6.57 & 8.77 & 0.00 & 0.76 & 1.13 & 5.56 & 0.93 & 2.19 & 9.13 & 0.03 & 6.27 & 0.00 & 0.10 & 0.00 & 0.00 & 0.00 & 0.00 \\
\hline IGA-70 & 0.01 & 0.00 & 0.37 & 0.34 & 0.00 & 0.06 & 0.09 & 0.38 & 0.06 & 0.16 & 12.24 & 0.02 & 20.60 & 0.00 & 0.16 & 0.00 & 0.00 & 0.00 & 0.00 \\
\hline IGA-74 & 0.20 & 0.00 & 4.77 & 6.83 & 0.00 & 1.49 & 0.37 & 4.17 & 0.69 & 2.06 & 11.13 & 0.03 & 9.23 & 0.00 & 0.15 & 0.00 & 0.00 & 0.00 & 0.00 \\
\hline IGA-77 & 0.01 & 0.00 & 0.25 & 0.36 & 0.00 & 0.11 & 0.16 & 0.45 & 0.07 & 0.28 & 20.07 & 0.03 & 23.19 & 0.00 & 0.33 & 0.00 & 0.00 & 0.00 & 0.00 \\
\hline IGA-82 & 0.02 & 0.00 & 0.07 & 0.08 & 0.00 & 0.22 & 0.31 & 0.12 & 0.02 & 0.56 & 65.53 & 0.21 & 26.28 & 0.00 & 0.35 & 0.00 & 0.00 & 0.00 & 0.00 \\
\hline IGA-87 & 0.01 & 0.00 & 0.33 & 0.38 & 0.00 & 0.09 & 0.13 & 0.34 & 0.06 & 0.23 & 17.06 & 0.04 & 14.35 & 0.00 & 0.18 & 0.00 & 0.00 & 0.00 & 0.00 \\
\hline IGA-92 & 0.01 & 0.00 & 0.50 & 0.43 & 0.00 & 0.08 & 0.12 & 0.60 & 0.10 & 0.22 & 11.90 & 0.03 & 17.12 & 0.00 & 0.15 & 0.00 & 0.00 & 0.00 & 0.00 \\
\hline IGA-96 & 0.01 & 0.00 & 0.26 & 0.28 & 0.00 & 0.04 & 0.07 & 0.26 & 0.04 & 0.12 & 12.27 & 0.02 & 15.40 & 0.00 & 0.17 & 0.00 & 0.00 & 0.00 & 0.00 \\
\hline IGA-99 & 0.11 & 0.00 & 2.63 & 2.69 & 0.00 & 0.35 & 0.48 & 1.76 & 0.29 & 0.93 & 11.22 & 0.04 & 7.55 & 0.00 & 0.18 & 0.00 & 0.00 & 0.00 & 0.00 \\
\hline IGA-102 & 0.01 & 0.00 & 0.47 & 0.40 & 0.00 & 0.07 & 0.10 & 0.56 & 0.09 & 0.18 & 10.67 & 0.02 & 19.47 & 0.00 & 0.16 & 0.00 & 0.00 & 0.00 & 0.00 \\
\hline IGA-106 & 0.02 & 0.00 & 0.41 & 0.55 & 0.00 & 0.09 & 0.12 & 0.50 & 0.08 & 0.22 & 12.72 & 0.03 & 13.89 & 0.00 & 0.14 & 0.00 & 0.00 & 0.00 & 0.00 \\
\hline IGA-109 & 0.22 & 0.00 & 3.45 & 6.27 & 0.00 & 0.63 & 0.87 & 3.77 & 0.63 & 1.73 & 10.89 & 0.03 & 6.70 & 0.00 & 0.03 & 0.00 & 0.00 & 0.00 & 0.00 \\
\hline
\end{tabular}




\begin{tabular}{|c|c|c|c|c|c|c|c|c|c|c|c|c|c|c|c|c|c|c|c|}
\hline IGA-111 & 0.01 & 0.00 & 0.21 & 0.45 & 0.00 & 0.03 & 0.05 & 0.14 & 0.01 & 0.09 & 9.48 & 0.01 & 13.06 & 0.00 & 0.08 & 0.00 & 0.00 & 0.00 & 0.00 \\
\hline IGA-118 & 0.01 & 0.00 & 0.28 & 0.45 & 0.00 & 0.06 & 0.08 & 0.23 & 0.01 & 0.15 & 13.29 & 0.02 & 19.80 & 0.00 & 0.11 & 0.00 & 0.00 & 0.00 & 0.00 \\
\hline IGA-132 & 0.01 & 0.00 & 0.33 & 0.45 & 0.00 & 0.07 & 0.10 & 0.38 & 0.02 & 0.18 & 13.21 & 0.03 & 14.22 & 0.00 & 0.09 & 0.00 & 0.00 & 0.00 & 0.00 \\
\hline IGA-147 & 0.02 & 0.00 & 0.54 & 0.52 & 0.00 & 0.07 & 0.10 & 0.43 & 0.02 & 0.19 & 11.12 & 0.03 & 10.66 & 0.00 & 0.07 & 0.00 & 0.00 & 0.00 & 0.00 \\
\hline IGA-161 & 0.01 & 0.00 & 0.54 & 0.51 & 0.00 & 0.10 & 0.14 & 0.46 & 0.03 & 0.25 & 14.16 & 0.03 & 17.68 & 0.00 & 0.08 & 0.00 & 0.00 & 0.00 & 0.00 \\
\hline IGA-175 & 0.03 & 0.00 & 0.62 & 0.57 & 0.00 & 0.07 & 0.10 & 0.54 & 0.03 & 0.20 & 10.05 & 0.05 & 6.33 & 0.00 & 0.08 & 0.00 & 0.00 & 0.00 & 0.00 \\
\hline
\end{tabular}

